\title{
Alkali-aggregate reaction in Swiss tunnels
}

\author{
A. Leemann ${ }^{1}$, C. Thalmann ${ }^{2}$ and W. Studer ${ }^{3}$ \\ (1) Swiss Federal Laboratories for Materials Testing and Research (EMPA), Überlandstr. 129, CH-8600 Dübendorf, Switzerland \\ (2) B-I-G Bureau of Engineering Geology, CH-3084 Wabern, Switzerland \\ (3) Contec, Frohbergstr. 9, CH-8620 Wetzikon, Switzerland
}

Received: 23 April 2004; accepted: 11 August 2004

\begin{abstract}
Currently the work for two new railway tunnels through the Swiss Alps with a length of 35 and $57 \mathrm{~km}$ respectively is in progress. Prepared aggregates quarried from the tunnels are reused for the concrete. About $50 \%$ of these aggregates are classified as reactive in regard to alkali-aggregate reaction (AAR) according to the AFNOR P 18-588 microbar test. In order to obtain information about AAR in concrete exposed to underground conditions, eight existing tunnels are investigared in this study. The concrete and shotcrete of the 16 coring sites studied is between 19 and 44 years old. The visual inspection of the tunnels and the physical properties of the concrete and shotcrete indicate no substantial damage although signs for AAR are present in the majority of the samples. Furthermore, the aggregates of seven coring sites are classified as reactive, but they obviously do not reach their reaction potential. A possible reason might be the minor climatic fluctuations in the tunnels. The results of this study indicate that reactive aggregates might be used for concrete in tunnels without causing damage due to AAR.

1359-5997 을 2004 RILEM. All rights reserved.

\section{RÉSUMÉ}

Actuellernent deux notveanx tunnels ferroviaires d'une longuetr de respectivement 35 et $57 \mathrm{~km}$, sont en cours de construction à trovers les Alpes suisses. Les déblais de roches produits par leur percement sont traités et recyclés comme gramulats pour la confection du béton utilisé dans ces tunnels. Selon les essais réalisés avec le test Microbar selon la notme AFNOR P 18-588, environ 50\% de ces gramulats sont à classer comine réactifs pour ce qui est de la réaction alcalis-gramulats (RAG). Afin d'obtenir des infonnations str la RAG dans le béton des tumnels, on a procédé à une étude sur huit tunnels existants. Le béton et le béton projeté des 16 carottages réalisés étaient âgés de 19 à 44 ans. L'inspection visuelle des tunnels ainsi que la détermination des caractéristiques mécaniques des bétons n'ont révélé aucun dommage substantiel, cela bien que la majorité des éprouvettes examinées présentât des signes d'une RAG. Par ailleurs les granulats de sept de ces carottages sont à classer comme réactifs. Manifestement ces granulats n'ont pas pu développer totalement leur potentiel de réactivité. Une des causes possibles de ce comportement potrrait résider dans les faibles variations climatiques existant dans les tumnels. Les résultats de cette étude montrent qu'il est passible d'utiliser des granulats réactifs pour les bétons destinés à être mis en place dans les tumnels sans qu'il se prochise de donmages par réaction alcalis-granulats.
\end{abstract}

\section{INTRODUCTION}

Damage due to alkali-aggregate-reaction in concrete are observed worldwide $[1,2]$. A variety of structures such as dams, bridges, walls and pavements are affected. In Switzerland the first case of AAR was published in 1995 [3]. In recent years several cases of AAR have been reported $[4,5]$.

Currently the work for two new railway tunnels through the Swiss Alps with a length of 35 and $57 \mathrm{~km}$ respectively is in progress. After being prepared rock quarried from the tunnels is used as aggregate for concrete applied in the tunnels. About $50 \%$ of these aggregates have shown a reaction potential for AAR in the microbar test [6]. The temperalure in the lunnels will reach up to $40^{\circ} \mathrm{C}$ due to their great depth. The relative humidity in the tunnels is expected to be between 40 and $80 \%$. These conditions would enable AAR to take place if the aggregate used is reactive and a sufficient amount of alkali ions in the pore solution of the concrete is present. Because the durability of the two structures is of vital importance for the European railway traffic, measures have to be taken to prevent damages caused by AAR [7]. Furthermore, a service life of 100 years without major repair work is required.

The aggregates and the concrete can be tested in regard to their reactivity. But in addition information about $A A R$ in underground structures is needed to assess the significance of the test results. In international literature there is little information about AAR in tunnels. In this study the concrete and shotcrete of eight existing tunnels are investigated in order to verify the existence of AAR in Swiss tunnels and to characterize the degree of damage present.

\section{Editorial Note}

The Swiss Federal Laboratories for Materials Testing and Research (EMPA) is a RILEM Titular Mernber.

Dr. Andreas Leemann participates in RILEM TC I88-CSC 'Casting of self-compacting concrete' and DSC 'Durability of self-compacting concrete'. Mr. Werner Studer is a RILEM Senior Member. 


\section{METHODS}

The age of the tunnels investigated ranges from 19 to 44 years. They are between 0.81 and $15.4 \mathrm{~km}$ long. The various tunnels are used for railways, roads or to lead water to reservoirs seasonally. Because AAR was not known in Switzerland at the time of their construction no measures to prevent AAR were taken. First, a visual inspection of parts of the tunnels was conducted over a total length of $28.2 \mathrm{~km}$. During these inspections indications for AAR such as typical crack patterns, pop outs and excessive deposits on the surface were recorded. Data about the temperature and the humidity were collected from the local authorities or were measured during the inspections and the coring. Cores with a diameter of $50 \mathrm{~mm}$ and various lengths were taken at 16 different sites where the concrete or shotcrete showed indications for AAR. No samples were taken within the portals. The concrete contains reinforcement and the shotcrete is not reinforced. The age of the samples taken for laboratory tests ranges from 19 to 44 years.

Flexural strength, compressive strength and porosity were measured according to SIA $162 / 1$ [8]. In the porosity test total porosity $n$ and the volume of capillary pores $w_{c p}$ were determined. Cores were crushed and the aggregates separated to study their petrography using a magnifier and a microscope on the size fraction $1.4 \mathrm{~mm}$ following RILEM method AAR-1 [9]. Additionally the potential reactivity was measured with the AFNOR microbar test [6]. This test method shows a good correlation (20 samples: $\left.\mathrm{R}^{2}=0.94\right)$ with the NBRI test $[10,11]$ and should therefore provide results comparable to other accelerated mortar bar test like the ASTM C 1260 [12] and the RILEM method AAR-2 [13]. In the AFNOR test a ratio of cement to aggregate (c/A) of 2, 5 and 10 is used. Because no aggregates with pessimum behaviour are known in Switzerland, the value obtained with a ratio c/A of 2 is used to classify the aggregates. According to their expansion the test samples are classified as not reactive, reactive or strongly reactive (NR: expansion $\leq 0.10 \%$, $\mathrm{R}$ : expansion $>0.10 \%$ $<0.20 \%$, SR expansion $\geq 0.20 \%$ ). Four quarries used to produce the aggregates for the concrete of seven different coring sites were located. The potential reactivity and the petrography of the recent production (grain size 4-8 $\mathrm{mm}$ ) in these quarries were studied. The microstructure of the concrete was examined with thin sections $\left(45 \times 70 \mathrm{~mm}^{2}\right)$ impregnated with fluorescent dyed epoxy resin using a polarization microscope. Additionally three fractured and uncoated samples of concrete were investigated with an environmental scanning electron microscope (ESEM-FEG XL30). The operating conditions of the ESEM were between $15-20 \mathrm{kV}$ and $0.5-$ 1.5 Torr. Energy dispersive X-ray spectroscopy (EDX) was used to identify the chemical compositions of minerals. The samples used to study the microstructure were taken from a depth relative to the concrete's original surface between 100 and $200 \mathrm{~mm}$.

\section{RESULTS}

\subsection{Visual inspection}

In all tunnels there are crack patterns in the concrete and shotcrete reminiscent of AAR. These cracks occur locally. Within the portals of the tunnels $A, E, F, G$ and $H$ the frequency of these cracks is increased. The surface of the concrete in tunnel $\mathrm{A}$ and $\mathrm{E}$ exhibits no sign of intruding groundwater. Locally there are wet spots and calcite deposits in the other tunnels. There was no substantial damage observed in the inspected parts of the tunnels.

The temperature in the different tunnels varies between 12 and $21^{\circ} \mathrm{C}$. The amplitude of the temperature fluctuations ranges from 2 to $6^{\circ} \mathrm{C}$. An exception is tunnel E. Because there are lateral openings it is exposed to outdoor conditions.

\subsection{Physical properties}

The compressive strength of the concrete and the shotcrete varies between 32-77 and 35-67 MPa respectively (Table 1). The values for flexural strength range from 4.2 to 7.1 $\mathrm{MPa}$ for the concrete and 4.5 to $6.7 \mathrm{MPa}$ for the shotcrete. The measurements for the porosity show big differences for total porosity $\mathrm{n}$ between 12.9 and 18.4 and 19.8 and 26.5 percent by volume respectively.

The compressive strength correlates well with the volume of capillary pores (Fig. 1):

$\mathrm{f}_{\mathrm{c}}=94.6-5.4 \cdot \mathrm{w}_{\mathrm{cp}} \quad \mathrm{R}^{2}=0.80$

The average compressive strength of the shotcrete is slightly higher at an identical volume of capillary pores compared to the concrete.

The compressive $\left(f_{c}\right)$ and flexural strength $\left(f_{f}\right)$ show a correlation (Fig. 2):

$\mathrm{f}_{\mathrm{f}}=0.104 \cdot \mathrm{f}_{\mathrm{c}} \quad \mathrm{R}^{2}=0.49$

\subsection{Petrographic examination}

Igneous rocks are the major component of all aggregates (53-93 percent by mass) except G1 ( 22 percent by mass / Table 2). They are deformed and altered in various degree and can be divided into granite, gneiss and schist. The major sedimentary rock types are sandstone, limestone, siliceous limestone and slate. Most of the aggregates

\begin{tabular}{|c|c|c|c|c|c|c|}
\hline \multicolumn{7}{|c|}{$\begin{array}{c}\text { Table 1 - Physical properties and porosity } \\
\text { (conc: concrete; shcr: shotcrete) }\end{array}$} \\
\hline Tunnel & Material & Age & $\begin{array}{c}f_{c} \\
{[\mathrm{MPa}]}\end{array}$ & $\begin{array}{c}f_{\mathrm{R}} \\
{[\mathrm{MPa}]}\end{array}$ & $\begin{array}{c}\mathrm{n} \\
{[\text { vol-\%] }}\end{array}$ & $\begin{array}{c}\mathrm{w}_{\mathrm{cp}} \\
{[\text { vol-\%] }}\end{array}$ \\
\hline A1 & conc & 22 & 59.9 & 6.3 & 15.1 & 6.0 \\
\hline A2 & conc & 22 & 32.2 & 4.5 & 16.4 & 10.6 \\
\hline A3 & shcr & 22 & 35.8 & 4.5 & 23.2 & 10.6 \\
\hline B1 & shcr & 21 & 48.3 & 5.5 & 24.7 & 9.3 \\
\hline C1 & conc & 21 & 47.4 & 5.1 & 18.4 & 8.8 \\
\hline C2 & shcr & 21 & 40.7 & 5.1 & 21.3 & 9.1 \\
\hline C3 & shcr & 21 & 54.8 & 5.6 & 21.7 & 8.6 \\
\hline D1 & conc & 21 & 76.9 & 7.1 & 13.2 & 3.8 \\
\hline D2 & shcr & 21 & 64.6 & 6.0 & 21.4 & 6.9 \\
\hline E1 & conc & 21 & 53.4 & 6.4 & 13.7 & 6.9 \\
\hline F1 & shcr & 19 & 52.2 & 5.4 & 20.2 & 7.2 \\
\hline F2 & shcr & 19 & 66.6 & 6.7 & 19.8 & 7.3 \\
\hline F3 & shcr & 19 & 34.5 & - & 26.5 & 12.0 \\
\hline G1 & shcr & 24 & 49.8 & 4.8 & 20.8 & 7.5 \\
\hline G2 & conc & 24 & 40.3 & 4.2 & 17.2 & 8.8 \\
\hline IH1 & conc & 44 & 57.4 & 5.8 & 12.9 & 5.8 \\
\hline
\end{tabular}




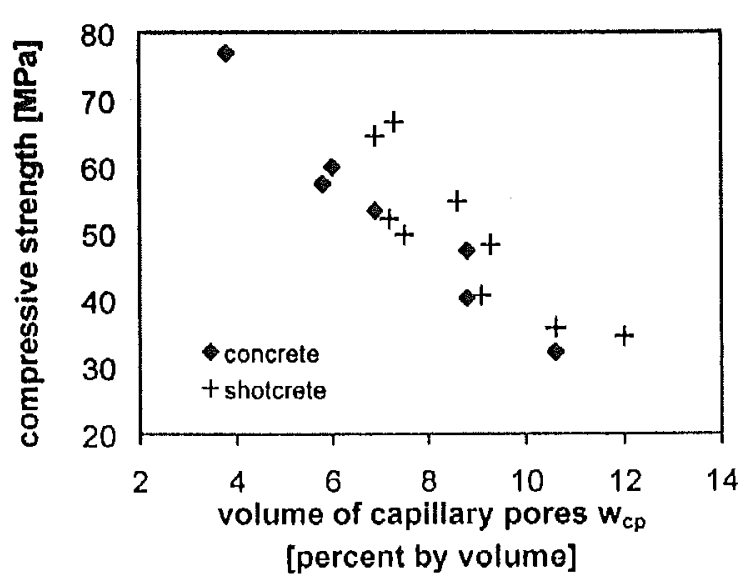

Fig. 1 - Compressive strength versus the volume of capillary pores $\mathrm{w}_{\mathrm{cp}}$.

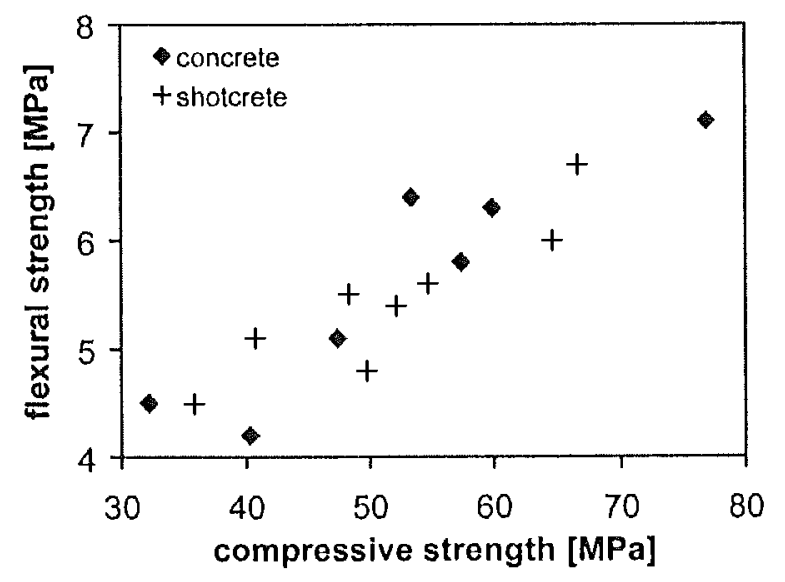

Fig. 2 - Flexural strength versus compressive strength.
Deformed quartz grains with undulary extinction and diffuse grain boundaries are present in the thin sections of all samples studied. Gneiss and schist always contain varying amounts of microcrystalline quartz. Feldspars altered to sericite are common as well. Biotite, muscovite and chlorite occur in all samples. There are gel deposits in air voids and cracks in six different samples (Table 3). All these samples show a distinct crack pattern including radial cracks running from aggregates into the hardened cement paste. Additionally five other samples without gel deposits show this crack pattern. The cracks occur in aggregates with a diameter greater than approximately 4 millimetres. The reactive aggregates identified are schist, gneiss and granite. In two cases cement with blastfurnace slag (about $30 \%$ of binder) was used (F2, D2). Otherwise ordinary Portland cement was applied.

In all three samples investigated with the ESEM quartz with dissolution features is observed. Additionally there is feldspar and biotite with dissolution phenomena in the samples $\mathrm{C} 2$ and C3 (Fig. 3, Table 4). In all samples there are deposits of gel in cracks and voids. The main component of the gels is always silicon and calcium with minor amounts of potassium and sodium. On the surface of few quartz minerals the formation of card house structured gel is observed (Fig. 4). This type of gel is present as well on the surface of quartz located at the edge of aggregates in all three samples studied.

The average expansion of the nine aggregates classified as NR is $0.058 \%$ with $0.040 \%$ (G1) being the lowest value (Table 4). Six aggregates are classified as R and one as SR.

\section{DISCUSSION}

At a relative humidity above $80 \%$ the expansion due to AAR is significantly increased $[14,15]$. The relative humidity in the majority of the tunnels is usually below $80 \%$. But the values in concrete in a depth greater than a few centimetres do not decrease below $80-90 \%$ even in dry conditions [15]. Locally the infiltration of groundwater leads to high moisture contents in the concrete and shotcrete. Consequently the climatic condition should enable AAR to occur.

The maximum temperature in the tunnels studied is $21^{\circ} \mathrm{C}$. Therefore no assessment can be made in regard to higher temperatures. But various laboratory studies have shown an acceleration of AAR with increasing temperatures [16].

contain minor amounts of mafic rocks. A part of the extracted aggregates consist of single minerals and can therefore not be related to a rock type ("fragments").

\subsection{Microscopy and microbar test}

In all cores aggregates with reactions rims at the edge are present. The number of aggregates affected varies strongly depending on the coring site.
There are no data available about the mix designs used for the concrete and shotcrete. Based on the results of the porosity and the compressive strength tests the cement content of the shotcrete can be estimated at $350 \mathrm{~kg} / \mathrm{m}^{3}$ for tunnel $F$ up to $400 \mathrm{~kg} / \mathrm{m}^{3}$ for tunnel $\mathrm{H}$. The estimation for the cement content of the concrele is between 300 and $360 \mathrm{~kg} / \mathrm{m}^{3}$. The $\mathrm{Na}_{2} \mathrm{O}$-equivalent of the Portland cements is supposed to be between 0.9 and $1.0 \%$ by mass concluding from the values of recent Swiss cement production. Conerete 


\begin{tabular}{|c|c|c|c|}
\hline \multicolumn{4}{|c|}{ Table 3 - Indications for AAR in the microstructure } \\
\hline Tunnel & $\begin{array}{c}\text { Reaction rims } \\
{[\%]}\end{array}$ & $\begin{array}{c}\text { Formation } \\
\text { of gel }\end{array}$ & $\begin{array}{c}\text { Radial } \\
\text { cracks }\end{array}$ \\
\hline A1 & $25-50$ & no & no \\
\hline A2 & $0-25$ & no & few \\
\hline A3 & $50-75$ & yes & few \\
\hline B1 & $0-25$ & no & no \\
\hline C1 & $0-25$ & no & few \\
\hline C2 & $25-50$ & yes & many \\
\hline C3 & $50-75$ & yes & many \\
\hline D1 & $0-25$ & no & no \\
\hline D2 & $0-25$ & yes & few-many \\
\hline E1 & $0-25$ & yes & few-many \\
\hline F1 & $0-25$ & no & few \\
\hline F2 & $0-25$ & no & few \\
\hline F3 & $25-50$ & no & no \\
\hline G1 & $25-50$ & no & few-many \\
\hline G2 & $50-75$ & yes & few-many \\
\hline H1 & $0-25$ & no & no \\
\hline
\end{tabular}

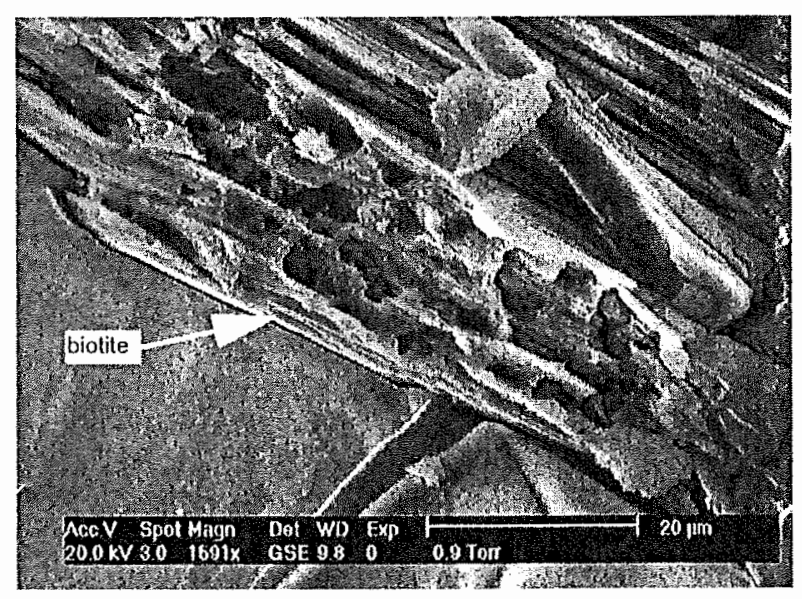

Fig. 3 - Biotite with dissolution features. Sample C2.

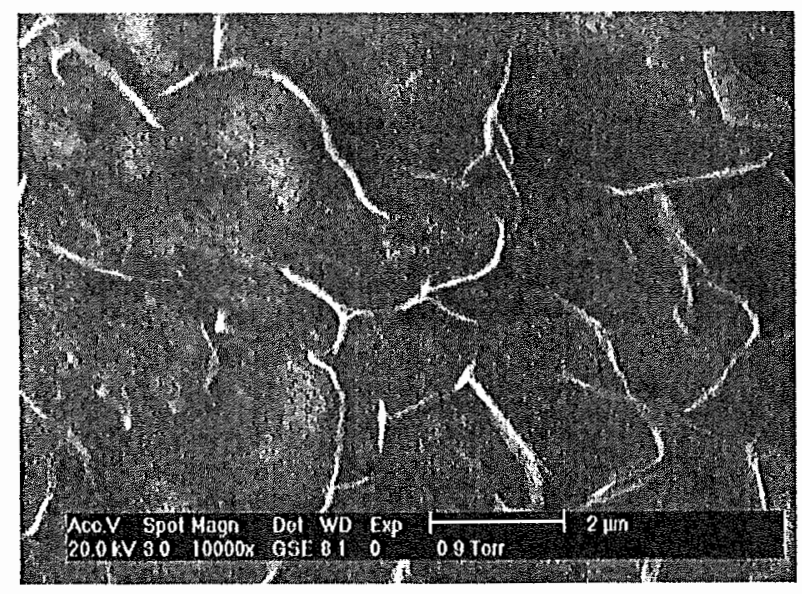

Fig. 4 - Formation of gel on surface of quartz. Sample C2.

performance tests conducted according to AFNOR P18-454 [17] with rocks excavated from the new railway tunnels show that the $\mathrm{Na}_{2} \mathrm{O}$-equivalent required for mixes with a high AAR resistance should be $<2.3 \mathrm{~kg} / \mathrm{m}^{3}$ for strongly reactive aggregates and $<3.3 \mathrm{~kg} / \mathrm{m}^{3}$ for reactive aggregates [7].

\begin{tabular}{|c|c|c|c|c|}
\hline \multicolumn{5}{|c|}{$\begin{array}{l}\text { Table } 4 \text { - Reactivity of the aggregates } \\
\text { (the terms in brackets show the microbar classification } \\
\text { determined in samples with similar petrography / } \\
\text { samples from quarries are printed in italics) }\end{array}$} \\
\hline $\begin{array}{l}\text { Tunnel, } \\
\text { quarry }\end{array}$ & $\begin{array}{l}\text { Reactive } \\
\text { rocks }\end{array}$ & $\begin{array}{l}\text { Reactive } \\
\text { minerals }\end{array}$ & $\begin{array}{c}\text { Microbar } \\
\text { expansion } \\
{[\%]}\end{array}$ & $\begin{array}{l}\text { Microbar } \\
\text { classifica } \\
\text {-tion }\end{array}$ \\
\hline A1 & none & $=$ & 0.074 & $\mathrm{NR}$ \\
\hline $\mathrm{A} 2$ & gneiss & - & 0.142 & $\mathrm{R}$ \\
\hline A3 & $\begin{array}{l}\text { gneiss, } \\
\text { schist }\end{array}$ & - & - & $\begin{array}{l}\text { (NR/R: } \\
\mathrm{A} 1, \mathrm{~A} 2)\end{array}$ \\
\hline B1 & none & - & - & - \\
\hline $\mathrm{Cl}$ & gneiss & - & 0.070 & NR \\
\hline $\mathrm{C} 2$ & $\begin{array}{l}\text { gneiss, } \\
\text { schist }\end{array}$ & $\begin{array}{l}\text { quartz, } \\
\text { feldspar, } \\
\text { biotite }\end{array}$ & 0.068 & NR \\
\hline C3 & $\begin{array}{l}\text { gneiss, } \\
\text { schist }\end{array}$ & $\begin{array}{l}\text { quartz, } \\
\text { feldspar, } \\
\text { biotite }\end{array}$ & - & $\begin{array}{c}\text { (NR: } \mathrm{C} 1, \\
\mathrm{C} 2)\end{array}$ \\
\hline D1 & none & - & 0.154 & $\mathrm{R}$ \\
\hline D2 & $\begin{array}{l}\text { sandstone } \\
\text { gneiss, } \\
\text { schist }\end{array}$ & - & - & $(\mathrm{R}: \mathrm{D} 1)$ \\
\hline E1 & gneiss & - & $=$ & (R:Dl) \\
\hline $\mathrm{F} 1$ & $\begin{array}{l}\text { gneiss, } \\
\text { granite }\end{array}$ & - & 0.052 & NR \\
\hline F2 & $\begin{array}{l}\text { gneiss, } \\
\text { granite }\end{array}$ & - & 0.056 & NR \\
\hline F3 & none & - & - & $\begin{array}{c}\text { (NR: F1, } \\
\text { F2) }\end{array}$ \\
\hline G1 & $\begin{array}{c}\text { gneiss, } \\
\text { schist }\end{array}$ & - & 0.040 & NR \\
\hline G2 & gneiss & quartz & 0.052 & NR \\
\hline $\mathrm{H1}$ & none & - & 0.130 & $\mathrm{R}$ \\
\hline$D 1, G 1$ & - & - & 0.272 & $S R$ \\
\hline$F 1, F 2$ & - & - & 0.065 & $N R$ \\
\hline$G 2, F 3$ & - & - & 0.046 & $N R$ \\
\hline$H I$ & - & - & 0.135 & $R$ \\
\hline
\end{tabular}

Concluding from these results the alkali content of the shotcrete and the majority of the concrete of the studied tunnels should be sufficient to enable AAR.

The results for porosity and compressive strength show that the concrete and the shotcrete in the different tunnels were produced with a wide variety of cement contents and w/b-ratios. The good correlation between compressive strength and the volume of capillary pores indicates that no significant damage is caused by AAR. In case of a substantial damage low values for compressive strength could be expected at a given volume of capillary pores. It is more usual in flexural strength to be impaired by AAR. The correlation between compressive and flexural strength seem to indicate no substantial damage as well.

Although higher cement contents are used in the shotcrete compared to the concrete, there are no differences between the two in regard to the degree of AAR. There is no correlation between the amount of aggregates with a dark rim and the occurrence of gel deposits and cracks in the corresponding concrete. The dark rims of the aggregates do 
not necessarily indicate AAR. Because the aggregate is quarried from alluvial deposits some of these reaction rims might be caused by weathering. However, in the two shotcrete and the concrete sample investigated with the ESEM gel was observed on the surface of quartz at the edge of aggregates with dark rims.

The observed crack pattern with radial cracks running from aggregates into the cement paste is a typical feature caused by the expansion of aggregates [1, 18]. Therefore it can be used as an indication for the presence of AAR.

The precipitation of gel in voids and cracks clearly indicates that a dissolution and subsequent precipitation of $\mathrm{SiO}_{2}$ takes place. The most frequently etched mineral in the three samples studied with the ESEM is quartz. However, dissolution features on feldspar and biotite indicate that in addition to $\mathrm{SiO}_{2}$ these minerals contribute alkali ions to the pore solution. It has been shown that milled feldspars release alkali ions when treated with alkaline solutions [19]. Apart from feldspar biotite and chlorite can be etched when stored in a $\mathrm{NaOH}$ or $\mathrm{Ca}(\mathrm{OH})_{2}$ solution [20]. The influence of alkali feldspar on the composition of the pore solution of mortars has been confirmed [21].

The test results for the potential reactivity of the aggregates extracted from the concrete do not necessarily represent its original reaction potential because some reaction might already have taken place in the concrete. But in general there is no big difference between the test results obtained with aggregates extracted from cores and aggregates directly sampled from the quarry. An exception is sample Gl. The aggregate extracted from the shotcrete is classified as NR, while the sample from the quarry is classified as SR although the petrographic examination shows a similar composition of the two. No explanation for this contradiction is found.

There is no clear correlation between the different indicators for AAR in the microstructure of the concrete. The formation of gel deposits and the occurrence of radial crack patterns are observed in six samples including one of the shotcretes with slag. But five samples with cracks do not show gel deposits. Obviously the expansion of aggregates is not always accompanied by the formation of gel deposits in air voids and cracks. The reason for this observation might be that AAR does not take place uniformly in the concrete and therefore there are differences in the spatial distribution of the indicators. Another possibility for the difference is the concentration and ratio of calcium, sodium and potassium in the pore solution favouring either dissolution with subsequent precipitation or expansion [22-24].

Even the samples with aggregates classified as NR show signs for AAR in the microstructure. Their mean expansion of $0.06 \%$ in the microbar test indicates a certain reactivity explaining this observation. None of the aggregates classified as reactive cause substantial damage of the concrete structures. In one case there is no indication for AAR at all. Obviously the aggregates do not display their reaction potential although the climatic conditions are appropriate. One of the reasons might be the minor climatic fluctuations in the underground structures. There are seasonal variations in temperature and humidity but no daily changes. It stands out that the frequency of cracks is increased within the portals of several tunnels. There the concrete is subjected to much greater variations of humidity and temperature. In concrete affected by daily variations in temperature an equilibrium regarding the moisture content cannot be achieved [25]. The moisture gradient is regarded as a major factor for ion migration [26]. Therefore the development of AAR could be influenced by the frequency of variations in temperature. Laboratory tests have shown that variations in temperature and humidity can accelerate the AAR [27]. On the other hand the suitability of accelerated test methods for predicting the expansion of concrete structures is still not documented sufficiently $[28,29]$.

Due to the results of this study reactive aggregates are currently used for concrete and shotcrete in the two new tunnels. The nieasures taken to prevent AAR are the use of cement with pozzolanic admixtures and the installation of liners to prevent the contact between concrete and ground water [7].

\section{CONCLUSIONS}

- AAR takes place in the concrete of tunnels with an age between 19 and 44 years.

- The field observations and the physical properties of the samples show that no substantial damage occurs although reactive aggregates and indication for $\mathrm{AAR}$ are present.

- There is no direct correlation between the amount of gel formed and the degree of cracking in shotcrete and concrete with AAR.

- The minor climatic fluctuations in the underground structures may not support the development of AAR and related damage.

- The influence of temperatures up to $40^{\circ} \mathrm{C}$ on the development of AAR in underground conditions is not known.

- The microbar test is able to identify potentially reactive aggregates and confirms the presence of AAR.

- It is necessary to use pozzolanic admixtures and to install liners preventing the contact between concrete and ground water in order to reduce the risk for AAR in the two new railway tunnels.

\section{ACKNOWLEDGMENTS}

The authors would like to thank Alptransit Gotthard AG for financing this study and L. Holzer for the support in the ESEM investigation.

\section{REFERENCES}

[1] Hobbs, D.W., 'Alkali-silica reaction in concrete' (Thomas Telford, London, 1988).

[2] Swamy, R.N., 'The alkali-silica reaction in concrete' (Blackie, Glasgow, 1992).

[3] Regamey, J.M. and Hammerschlag, J.G., 'Barrage de l'Illsee - assainissement', Research and Development in the Field of Dams, Proceedings of ICOLD-Symposium (Crans-Montana, Switzerland, 1995).

[4] Leemann, A., Thalmann, C. and Kruse, M., 'Broken Aggregates', Schweizer Ingenieur- und Architektenverein, $S I+A 24$ (1999) 4-8 [only available in German]. 
[5] Thalmann, C., Zingg, J., Rytz, G., Strahm, K. and Wyss, C., 'Prevention of damage to concrete structure due to alkaliaggregate reaction', Schweizer Ingenieur- und Architektenverein, tec 2115 (2001) 2-8 [only available in German].

[6] AFNOR P18-588, 'Granulats - stabilité dimensionnelle en milieu alcalin (essai accéléré sur mortier MICROBAR), Association Française de Normalisation (Paris, 1991).

[7] Thalmann, C., 'AAR-prevention for the world's longest tunnel - AlpTransit Gotthard and Lötschberg in Switzerland', Proceedings of the $12^{\text {th }}$ ICAAR (Beijing, China, 2004) accepted.

[8] SIA 162/1, 'Concrete structures', Materialprüfungen, Schweizer Norm 562 162/1 (1989) [only available in German].

[9] Sims, I. and Nixon, P., 'RILEM Test recommended test method AAR-1: Detection of potential alkali-reactivity of aggregates - petrographic method', Mater. Struct. 36 (2003) 472-479.

[10] Hammerschlag, J.-G. and Zgraggen, P., 'Assessment of the alkali-aggregate reaction of the aggregates and some concrete mixes for the Alptransit tunnel projects Gotthard and Lötschberg', TFB-Bericht, Projekt 998055, Ref. $05.001 / 2$ (2000) [only available in German].

[11] Oberholster, R.E., "Alkali reactivity of siliceous rock aggregates: diagnosis of reaction, testing of cement and aggregate and prescription of preventive measures' Proceedings of the $6^{\text {th }}$ ICAAR (Copenhagen, Denmark, 1983) 419-433.

[12] ASTM C 1260-01, 'Standard test method for potential alkali reactivity of aggregates (mortar-bar method)', ASTM Standards in Building Codes (2003) 681-85.

[13] RILEM TC-106-2, 'Detection of potential alkali-reactivity of aggregates - The ultra-accelerated mortar-bar test', Mater. Struct. 33 (2000) 283-293.

[14] Nilsson, L.O., 'Moisture effects on the alkali-silica reaction', Proceedings of the $6^{\text {th }}$ ICAAR (Copenhagen, Denmark, 1983) 201-208.

[15] Poole, A.B., 'Introduction to alkali-silica reaction in concrete', in: Swamy, R.N., 'The alkali-silica reaction in concrete' (Blackie, Glasgow, 1992) 1-29.

[16] Jones, F.E. and Tarleton, R.D., 'Reactions between aggregates and cement', National Building Research Paper 25, Pt IV. (HMSO, London, 1958).
[17] AFNOR P18-454, 'Réactivité d'une formule de béton vis-dvis de l'alcali-réaction (essai de performance)', Association Française de Normalisation (Paris, 2004).

[18] St. John, D.A. Poole, A.W., and Sims, I., 'Concrete Petrography' (Arnold, London, 1998).

[19] Bérubé, M.A., Duchesne, J., Dorion, J.F. and Rivest, M., 'Laboratory assessment of alkali contribution by aggregates to concrete and application to concrete structures affected by alkali-silica reactivity', Cem. Concr. Res. 32 (2002) 1215-1227.

[20] Leemanı, A. and Holzer, L., 'Alkali-aggregate-reaction: identification of reactive silicates', Proceedings of the $9^{\text {th }}$ Euroseminar of Microscopy (Trondheim, Norway, 2003).

[21] Constantiner, D. and Diamond, S., 'Alkali release from feldspars into pore solutions', Cem. Concr. Res. 33 (2003) 549-554.

[22] Rodrigues, F. A., Monteiro, P.J.M. and Sposito, G., 'The alkali-silica reaction: the surface charge density of silica and its effect on expansive pressure', Cem. Concr. Res. 29 (1999) 527-530

[23] Chatterji, S. and Thaulow, N., 'Some fundamental aspects of alkali-silica reaction', Proceedings of the $11^{\text {th }}$ ICAAR (Québec, Canada, 2000) 21-29.

[24] Kawamura, M. and Iwahori, K., 'ASR gel composition and expansive pressure in mortars under restraint', Cem. Concr. Comp. 26 (2004) 47-56.

[25] Andrade, C., Sarria, J. and Alonso, C., 'Relative humidity in the interior of concrete exposed to natural and artificial weathering', Cem. Concr. Res. 29 (1999) 1249-1259.

[26] Xu, Z. and Hooton, R.D., 'Migration of alkali ions in mortar due to several mechanisms', Cem. Concr. Res. 23 (1993) 951-961.

[27] Dombrowski, K., 'Influence of aggregates on the durability of concrete', $\mathrm{PhD}$ Thesis, Bauhaus-Universität Weimar (Germany, 2003) [only available in German].

[28] Grattan-Bellew, P.E., 'A critical review of ultra-accelerated tests for alkali-silica reactivity', Cem. Concr. Comp. 19 (1997) 403-413.

[29] Whiting, N.M., 'Comparison of field observations with laboratory test results on concretes undergoing alkali-silica reaction', Cem. Concr. Aggr. 21 (2) (1999) 142-148. 